The article proves that a speech disorder caused by Progressive Supranuclear Palsy is one of the first features revealed at the beginning of the desease.

The main goal in speech therapy is to raise the effectiveness, efficiency and clarity in the process of communication. The approaches of treatment of speech disorders depend on pathophysiology and specific abnormal speech characteristics as well as multiple additional factors such as etiology, prognosis, disability, communication needs, societal limitations.

The approaches to managment include medical intervention with speech-oriented treatment by modifying respiration, phonation, articulation, resonance, prosody and communication-oriented treatment by alternative and augmentative communication not neglecting counseling and support.

Key words speech impairment, progressive supranuclear palsy, dysarthria.

удк 378.018.8:376-056.264-051

Цимбал-Слатвінська Світлана

Уманський державний педагогічний

університет імені Павла Тичини

ORCID ID 0000-0002-2732-5716

DOI 10.24139/2312-5993/2019.07/026-037

\title{
ОСОБЛИВОСТІ ПРОФЕСІЙНОЇ ПІДГОТОВКИ МАЙБУТНІХ ЛОГОПЕДІВ У ЗАКЛАДАХ ВИЩОЇ ОСВІТИ В АСПЕКТІ ПРОФЕСІЙНОї ДІЯЛЬНОСТІ
}

У статті розкрито особливості професійної підготовки майбутніх логопедів у закладах вищої освіти в аспекті професійної діяльності. Для їх розкриття визначено сферу діяльності, функції, вимоги до підготовки майбутніх логопедів у закладах вищої освіти. Установлено, що головним обов'язком логопеда є виявлення та надання допомоги дітям із різними аномаліями у психофізичному розвитку. Розкрито специфіку корекційно-розвивальної діяльності майбутнього логопеда, яка полягає в тому, що його мовлення, сфрормована комунікативна компетентність є інструментами корекційного впливу, від ефективності застосування залежать можливості подальшого розвитку та соціалізації дітей і підлітків з вадами мовлення, а також успішність професійнопедагогічного спілкування з ними, їхніми батьками, колегами, адміністрацією.

Ключові слова: особливості, професійна підготовка, майбутні логопеди, закладах вищої освіти, професійна діяльність.

Постановка проблеми. Неухильне зростання кількості дітей, які мають різні форми відхилень у мовленнєвому розвитку, актуалізує потребу у кваліфікованих логопедах. Особливість професії логопеда полягає в тому, що за своєю сутністю вона орієнтована на допомогу іншим людям. Тому вибір саме такої професії передбачає чітко виражену гуманістичну орієнтацію (орієнтацію на людину з їі проблемами). Гуманізація ставлення суспільства до осіб із проблемами в розвитку та інтеграція їх в усі сфери соціального життя вносить суттєві корективи в їхню професійну діяльність (Бессмертная, 2003).

Гуманне ставлення до дітей із мовленнєвими порушеннями може забезпечити тільки особистісно зрілий професіонал, вільний від внутрішньо особистісних конфліктів, відкритий зовнішньому світу, готовий 
у будь-який момент допомогти дитині. Ефективність роботи логопеда залежить і від його впевненості в оптимістичній перспективі корекційновідновлювального впливу (Стахова, 2010).

Звідси однією з цілей підготовки майбутнього логопеда $є$ орієнтація на своєчасне виявлення й подолання відставань та відхилень у розвитку мовлення дитини, що має виняткове значення для формування ії особистості, для підготовки до шкільного навчання і безпосереднього навчання в школі.

Аналіз актуальних досліджень. Останнім часом підготовку дефектологів (логопедів) з вищою професійною освітою досліджували Р. Агавелян, Д. Азбукін, Р. Аслаєва, Т. Баєва, Н. Басалюк, В. Гладуш, Т. Дегтяренко, О. Дружиловська, Н. Заварова, Б. Зодбаєва, О. Колишкін, В. Липа, М.Перова, В. Синьов, В. Течиєва, А. Шевцов, М.Шеремет, Л. Ястребова за базовими напрямами: сурдопедагогіка (від лат. Surdus глухий), тифлопедагогіка (від rp. Typhlos - сліпий), олігофренопедагогіка (від rp. Oligos - малий, незначний + phren - розум) та логопедія (від rр. Logos - слово, мова, зміст, розум, міркування, поняття, вчення, наука + paideia виховання, навчання). Науковцями доведено, що виділення самостійних галузей логопедії відбувалося поступово в міру накопичення теоретичних знань, методичного інструментарію та практики реального функціонування спеціальних (корекційних) освітніх закладів. Ці напрями створюють базу для навчання й виховання дітей із проблемами розвитку, з відхиленнями у розвитку, з вадами психофізичного розвитку, зокрема 3 мовленнєвими порушеннями.

Отже, як вузький фахівець логопед належить до об'єднання дефектологів, головним обов'язком яких $\epsilon$, перш за все, виявлення та надання допомоги дітям із різними аномаліями у психофізичному розвитку. Така соціальна позиція дефектологів ґрунтується на розумінні головної ролі системи корекційно-освітніх заходів для психічного розвитку дітей, які мають вади в сенсорній (порушення зору, слуху), моторній (порушення опорно-рухового апарату), мовленнєвій та інтелектуальній сферах, і активізації їхніх компенсаторних можливостей. Ефективність педагогічного впливу істотно залежить від забезпечення таких умов. Поперше, корекція вад розвитку і формування основних умінь і навичок чіткіше відбувається в оптимальні (сенситивні) для їх виникнення вікові періоди. По-друге, система заходів повинна бути адекватна можливостям тієї або іншої дитини і враховувати своєрідність властивих їй особливостей пізнавальної діяльності (Стахова, 2010).

Головна відмінність корекційної діяльності полягає в тому, що спектр установ, де може працювати логопед, надзвичайно широкий. Він включає не тільки різні типи й види освітніх організацій, а й організацій охорони здоров'я, соціального захисту, психолого-медико-педагогічні консультації. I майбутній логопед, який отримав диплом, повинен добре орієнтуватися в цій 
величезній професійній сфері. Істотна відмінність спеціальності «логопед» від інших педагогічних спеціальностей полягає ще в тому, що бакалавр-логопед у процесі навчання повинен бути підготовлений до роботи 3 різними категоріями дітей (за віком: діти дошкільного, шкільного віку, дорослі; за діагнозом: дизартрія, ринолалія, дисфонія, полтерн, тахілалія, браділалія, $з$ порушеннями лексико-граматичної будови, з порушеннями фонематичного сприйняття, алалія, заїкання, дисграфія, дислексія, афазія).

Необхідно відзначити, що робота логопеда з різними категоріями дітей неоднакова, вона має чітко виражену специфіку в різних корекційних освітніх організаціях і службах.

Отже, свою діяльність майбутній логопед може здійснювати в закладах дошкільної освіти (логопедичні, компенсаторні та інклюзивні групи), закладах загальної середньої освіти, спеціальних, навчально і соціально реабілітаційних центрах, логопунктах при поліклініках, ПМПК (нині - ІРЦ).

Як зазначає Н. Безсмертна, спеціаліст може працювати з дітьми в сім'ї, у різних типах установ, орієнтованих на надання консультативнодіагностичної, корекційно-педагогічної, реабілітаційної та іншої спеціалізованої допомоги дітям з проблемами в розвитку (Бессмертная, 2003).

Метою статті $€$ визначити особливості професійної підготовки майбутніх логопедів у закладах вищої освіти в аспекті професійної діяльності.

Методи дослідження. У статті використано методи дослідження: теоретичні (аналіз філософської, педагогічної, психологічної літератури), для обґрунтування вихідних положень дослідження; інтерпретаційноаналітичний метод, на основі якого вивчаються українські й зарубіжні джерела із застосуванням синтезу, аналізу, систематизації та узагальнення.

Виклад основного матеріалу. Логопеди працюють як $з$ дітьми, так і 3 дорослими, які мають мовленнєві порушення (невміння вимовляти певні звуки, заїкання тощо). Перш за все, фахівець визначає причину мовленнєвих недоліків. Для цього потрібно знати, як влаштована ротова порожнина, яким чином відтворюються звуки, утворюється голос. Оволодіння практичними навичками під час корекції звуковимови неможливе без знання правильної будови органів апарату артикуляції під час проголошення кожного звука, з одного боку, і з іншого боку, без уміння повторити і відчути причину неправильної вимови звука. Тобто логопед повинен навчитися відчувати всі відхилення від норми під час вимови кожного звука (Акименко, 2003). На це вказує і Н. Безсмертна, яка вважає, що професійна діяльність фахівця спрямована на визначення причин, симптоматики порушень мовлення в дітей; дослідження структури мовленнєвих порушень та впливу їх на психічний розвиток дитини; застосування науково обґрунтованих методів психолого-педагогічної діагностики, корекції і профілактики різних форм мовленнєвих порушень; вивчення закономірностей спеціального навчання і 
виховання дітей із порушенням мовленнєвого розвитку й організацію логопедичної допомоги (Бессмертная, 2003).

Спираючись на еволюційно-онтогенетичний підхід, Н. Семаго виділяє основні напрями в системі підготовки майбутніх логопедів: визначення шляхів і засобів розвивально-корекційної роботи з дитиною, а також прогноз ії розвитку і можливостей на основі виявлених особливостей розвитку (незрілість або порушення в когнітивній, моторній, емоційноособистісній сферах і поведінки в цілому); реалізації інтегративно спланованої розвивально-корекційної роботи в процесі самого розвитку дитини (Семаго та Семаго, 2000).

Зазначені вимоги до професійної підготовки майбутнього логопеда висувають і особливі вимоги до його особистості. Логопед повинен володіти вмінням проводити психолого-педагогічне обстеження з метою визначення ходу психічного розвитку відповідно до вікових норм, а також: методами диференціальної діагностики для визначення типу порушень; методами консультування дітей та дорослих із відхиленнями в мовленнєвому розвитку, їхніх батьків і педагогів з проблем навчання, розвитку, життєвого і професійного самовизначення; методами психопрофілактичної роботи, спрямованої на створення сприятливого психологічного клімату в закладі освіти, сім'ї; уміннями і прийомами навчання дітей із порушеннями мовлення навчальних предметів у загальноосвітніх спеціальних корекційних установах; методами виховання дітей із мовленнєвою патологією тощо (Жукатинская, 2008).

Логопед повинен уміти точно діагностувати мовленнєві порушення, володіти прийомами й методами їх усунення та корекції, проводити профілактичну роботу з їх запобігання, володіти спеціальними методами навчання дітей із мовленнєвими розладами рідної мови як у дошкільному, так і в шкільному віці, добре знати психологічні особливості дітей із мовною патологією, володіти прийомами й методами їх виховання, корекції та розвитку в них вищих нервових функцій. Специфічним для такого логопеда $\epsilon$ те, що він одночасно виконує і психологічну та педагогічну корекцію. Слушною є думка Л. Волкової, С. Шаховської, що особистість учителя-логопеда, його стан, включеність у корекційнопедагогічне навчання дітей дошкільного й молодшого шкільного віку повністю відображаються на стані, поведінці, особистісних проявах дітей у наступні роки (Логопедия, 1998). Успіх у виконанні цих завдань залежить від наявності в нього глибоких професійних знань і навичок, широкої орієнтації в сучасних і зарубіжних досягненнях суміжних із логопедією наук, а також від його творчої активності та ініціативи.

Специфіка корекційно-розвивальної діяльності майбутнього логопеда полягає в тому, що його мовлення, сформована комунікативна компетентність $€$ інструментами корекційного впливу, від ефективності 
застосування залежать можливості подальшого розвитку та соціалізації дітей і підлітків з вадами мовлення, а також успішність професійно-педагогічного спілкування з ними, їхніми батьками, колегами, адміністрацією.

Застосування традиційних прийомів роботи не завжди дозволяє отримати бажаний результат, на допомогу приходять медіа-технології. Це дозволяє вирішити низку таких проблем сучасної корекційної педагогіки: розробку технологій виявлення співвідношення між розвитком i навчанням; побудову нових шляхів навчання; розробку нових педагогічних технологій вирішення традиційних корекційних та освітніх завдань; розробку нового змісту підготовки логопедів, які працюють із дітьми 3 вираженими порушеннями в розвитку мовлення.

Логопед забезпечує якісну індивідуалізацію освітнього процесу, а дитина отримує усну інструкцію, щоб пройти шлях від спільно-розділеної діяльності з комп'ютером до спільної роботи з партнером-однолітком і, нарешті, до повної самостійної індивідуальної навчальної діяльності.

Одним із основних механізмів оволодіння дітьми рідною мовою $\epsilon$ наслідування. Саме в дошкільний період, як указує Н. Болтакова, дитина активно засвоює рідну мову, що є носієм і транслятором культури народу, унікальним способом передачі людського досвіду і засобом пізнання навколишнього світу (Болтакова, 2013).

Для тих, хто спеціально покликаний вирішувати завдання мовленнєвого й лінгвістичного розвитку, навчання дітей мовлення (до них, у першу чергу, слід віднести вихователів дошкільних освітніх установ, учителів початкових класів, учителів-логопедів), необхідно забезпечити підготовку, яка охоплює ширший діапазон компонентів, включаючи лінгвістичний та методичний складники.

Професійну діяльність майбутнього фахівця Н. Болтакова пропонує розглядати через такі складові компоненти (етапи): визначення широти сфери діяльності фахівця, виявлення узагальнених трудових функцій, аналіз структури праці, аналіз професійних функцій, аналіз труднощів і помилок, аналіз прогнозу сфери праці (Болтакова, 2011).

Ефективність професійної діяльності, на думку Р. Султанової, оцінюється за трьома основними параметрами: продуктивністю (вирішення поставлених завдань у мінімальні терміни); якістю (відношення числа вирішених завдань до загальної кількості поставлених завдань); задоволеністю (виконання завдань оптимальними засобами в найкоротший термін з мінімальними затратами) (Султанова, 2005).

Здійснена характеристика особливостей професійної підготовки майбутніх логопедів потребувала аналізу посадових обов'язків, функцій логопеда, особливостей професійної діяльності, специфічних професійно значущих якостей. 
Зміст посадових обов'язків логопеда передбачає, що він повинен бути підготовлений до активної творчої, професійної діяльності; уміти оцінювати з позицій діалектичного підходу сучасні процеси і проблеми суспільного життя країни; уміти визначати місце та роль у ній своєї професійної діяльності, проблеми й тенденції світового суспільного розвитку; уміти аргументовано відстоювати свою точку зору; мати навички колективної і соціальної діяльності.

На основі визначених професійних обов'язків логопеда позначено ті галузі знань, умінь, навичок, у яких студенти повинні бути компетентні: здійснює навчальну, корекційну, компенсаційну, реабілітаційну роботу 3 дітьми, які мають мовленнєві порушення, забезпечує умови для засвоєння інвалідами компенсаційно-корекційних програм із урахуванням порушень, вікових та індивідуальних особливостей, сприяє їх соціальній реабілітації, профорієнтації, вивчає та фіксує динаміку розвитку дитини, створює сприятливі організаційно-педагогічні умови для дітей із тяжкими мовленнєвими порушеннями (з ринолалією, заїканням, алалією, афазією, дизартрією), виробляє оптимальну педагогічну й корекційну стратегію; проектує шляхи навчання, реабілітації та соціальної адаптації кожної дитини, обирає ефективні форми, методи, засоби корекційно-реабілітаційного процесу, надає батькам або сім'ям консультативну допомогу щодо виправлення дефектів усного та писемного мовлення їхніх дітей, проводить із дітьми фронтальні, групові та індивідуальні заняття, виховує в дітей почуття впевненості в собі, усвідомлення своїх досягнень в опануванні методів, що можуть компенсувати обмеження, спричинені мовленнєвими порушеннями.

Логопед повинен вести пошук найкращих засобів корекції мовлення дітей, узагальнюючи передовий досвід. Уміння, якими він повинен володіти, широкі й різноманітні: навчально-пізнавальні (робота 3 літературою, спостереження за дитиною, моделювання педагогічного процесу, вибір оптимальних шляхів корекційного впливу); навчально-організаційні (перспективне й календарне планування, проведення індивідуальних та групових занять, створення наочності, забезпечення комплексності впливу та визначення в цьому комплексі своєї реальної участі); навчально-педагогічні (аналіз кожного випадку, вибір адекватних засобів корекції) (Жукатинская, 2008).

Виокремлення посадових обов'язків логопеда допомогло встановити особливості його професійної діяльності. Під особливостями розуміємо властивості, обумовлені здатністю виконувати певні специфічні професійні обов'язки, що відрізняють його як фахівця від інших.

Емпіричний аналіз показує, що логопед $\epsilon$ поліфункціональним фахівцем. Його діяльність має кілька характеристик.

Перша характеристика - поліфункціональність його діяльності. Функція (лат. Functio - виконання) - обов'язок, коло діяльності, 
призначення, роль. Поліфункціональність (Polu - численний і лат. Functio функція) - поєднання різних (зазвичай двох) функцій в одній.

До основних функцій логопеда науковці (Е. Борисова, Л. Волкова, Е. Жукатинська, Б. Зодбаєва, Л. Ястребова та ін.) відносять:

1) діагностичну - виявляється в обстеженні дітей і визначенні типу порушень. Вона передбачає оволодіння діагностичним інструментарієм 3 метою його застосування в корекційній діяльності, установлення умов, що здійснили негативний вплив на хід мовленнєвого розвитку, виявлення причин і механізмів порушень мовлення. Не менш важливим є вивчення впливу сім'ї на процес мовленнєвого й розумового розвитку дитини;

2) корекційну - участь логопеда у здійсненні системи спеціальних логопедичних заходів, спрямованих на подолання або послаблення недоліків розвитку, властивих дітям із порушеннями мовлення, що сприяють не тільки виправленню окремих порушень, а й формуванню особистості в цілому. Виділення цієї функції передбачає визначення основних напрямів корекційного впливу, планування цілей, завдань здійснення корекційнорозвивальної роботи з дітьми з порушенням мовлення, визначення змісту корекційно-освітніх програм для дітей із порушенням мовлення в умовах різних типів освітніх установ, здійснення відбору методик і технік корекційнорозвивальної роботи з урахуванням механізмів мовленнєвого порушення, структури дефекту, ступеня його прояву;

3) навчальну - виражається у стимуляції та управлінні активністю дитини, у результаті якої в неї формуються певні знання, уміння й навички;

4) організаційну. У межах цієї функції діяльність логопеда спрямована на створення сприятливих умов для загального й мовленнєвого розвитку дитини, усунення несприятливих факторів, що негативно впливають на розвиток дитини, установлення педагогічно доцільних відносин із дітьми 3 порушенням мовлення, їхніми батьками, надання оперативної допомоги дітям із порушеннями мовлення, створення психологічно комфортної атмосфери під час організації різних видів діяльності;

5) виховну - проявляється у процесі цілеспрямованого формування гармонійно розвиненої особистості з допомогою спеціально розроблених і науково обґрунтованих засобів, форм і методів впливу. Ця функція включає керівництво взаємовідносинами дітей із метою створення педагогічно доцільного, сприятливого мікроклімату для психічного розвитку кожної дитини. У межах цієї функції логопед забезпечує цілеспрямовану взаємодію $з$ дітьми з порушенням мовлення і найближчим оточенням (сім'я, родичі);

6) дослідницьку - діяльність логопеда неможлива без глибокого аналізу досвіду логопедичної та педагогічної діяльності, без щоденного пошуку нового, аналізу передового досвіду й нововведень;

7) функція психолого-педагогічної освіти батьків забезпечує єдність зусиль дитячого закладу та сім'ї, логопед виступає перед батьками як 
пропагандист логопедичних i педагогічних знань. Без виховної, просвітницької роботи з батьками неможливо домогтися значних успіхів у формуванні особистості дитини;

8) функція самоосвіти - працювати сьогодні на рівні сучасних вимог логопеду неможливо без постійного збагачення знаннями 3 нових досліджень у галузі педагогіки, психології, медицини та логопедії, тому цій функції надається особливе значення.

Поліфункціональність передбачає вміння знаходити неординарні рішення проблеми, орієнтуватися в стрімкому потоці застарілих знань, приймати виважені рішення (Аслаева, 2011).

Горизонти поліфункціональності змісту діяльності логопеда розширюються в умовах інтегрованого та інклюзивного навчання, а також створення в усіх дитячих освітніх установах психолого-медико-педагогічних консиліумів. Так, наприклад, випускник педагогічного коледжу, вступивши на логопедичну спеціальність закладу вищої освіти і здобувши ії через декілька років, одночасно виконує свої основні функції в дошкільному закладі як вихователь і додатково - функції логопеда в умовах інтегрованого навчання та інклюзивної освіти. Крім того, він вирішує типові професійні завдання у спеціальних (корекційних) освітніх дошкільних та медичних установах, центрах реабілітації та корекції, психолого-медико-педагогічних комісіях, консультаціях і консиліумах. У процесі такої освіти його діяльність стає поліфункціональною, багатоаспектною, різнорівневою як по вертикалі, так i по горизонталі. Вертикальна поліфункціональність передбачає багатоаспектну наступність завдань на різних етапах надання допомоги залежно від моделі взаємодії органів управління і спеціальної практичної служби допомоги з урахуванням вертикальних та горизонтальних структур. Горизонтальна поліфункціональність - це розширення змісту освітньої роботи в структурній єдності їі складових частин. Наприклад, на горизонтальній площині розташовані спеціальні загальноосвітні заклади різних типів.

Використання принципу поліфункціональності й багаторівневості передбачає серйозну перебудову навчального процесу, його змісту, форм і методів навчання.

Друга характеристика - багатоаспектність (внутрішня і змістова інтегрованість), сутність якої полягає в поєднанні різних напрямів (педагогічного, психологічного, соціального, медичного) в діяльності логопеда, необхідних для роботи в межах виконання своїх функціональних обов'язків. Вона також передбачає роботу логопеда на стратегічному або тактичному рівнях взаємодії (регіональні, районні або міські, первинні (локальні) установи). Багатоваріантність передбачає створення в освітній системі умови вибору та надання кожному суб'єктові шансу на успіх, стимулювання студентів до самостійності і прийняття відповідального рішення, забезпечення розвитку альтернативного мислення. 
Третя характеристика - різнорівневість (зовнішня та інституційна інтегрованість), яка означає врахування видового різноманіття освітніх установ, видів, типів, особливостей освітніх систем, також супровід дітей дошкільного, молодшого, старшого шкільного віку, дорослих із проблемами в розвитку (різний віковий рівень дітей із обмеженими можливостями здоров'я, з різним ступенем порушених функцій, різні методики навчання, розвитку та формування, прийоми і методи корекції тощо). Різнорівневому характеру соціального, психічного, мовленнєвого розвитку дітей із різними порушеннями на кожному рівні відповідає своя картина когнітивного розвитку, що безпосередньо пов'язана з чіткістю і локалізацією органічної та функціональної недостатності центральної нервової системи.

Четверта характеристика - багатогранність (має множинні прояви в системі) функцій логопеда. Вона дозволяє розглянути систему як багаторівневу структуру, компоненти якої мають деяку впорядкованість, підпорядкованість, ієрархічність, чим забезпечується диференціація рівнів освіти для раціонального заповнення професійних ніш на ринку праці. Кожен рівень соціальної освіти має свої цілі, завдання, форми й методи навчання. Багатогранність означає також поступовість, поетапність формування професійних знань, умінь на всіх рівнях підготовки, їх зв'язок і розвиток. Багаторівневість передбачає організацію етапності освітнього процесу, забезпечує можливість досягнення на кожному етапі освіти того рівня освіченості, який відповідає можливостям та інтересам особистості.

Ці функції і види діяльності властиві тільки логопеду, вони суто специфічні. Під «специфічністю» маємо на увазі відмінну характеристику, особливість явища, предмета, що відрізняється від інших за структурою діяльності, складом, характером, типологією, класифікацією, способами здійснення, підходами, методиками й засобами, яка характерна виключно для спеціальності логопеда.

Специфічні види професійної діяльності відображаються і в організації, і в змісті, методах і засобах, як у діяльності логопеда, так і в освітній діяльності дитини, що дає нам право назвати ці функції логопеда специфічними.

Висновки та перспективи подальших наукових розвідок. Отже, специфічні функції логопеда - це власне специфічні функції і види діяльності, властиві лише логопедові, які відрізняються від інших функцій і видів діяльності за способом здійснення, структурою й характером дій. Специфічні види професійної діяльності відображаються в організації та змісті діяльності логопеда на всіх рівнях надання допомоги дітям із порушеннями мовлення.

Очевидно, що діяльність майбутнього логопеда характеризується більш складною організацією, яка потребує погодження в діях дітей, їхніх батьків, лікарів, спеціального психолога, соціального педагога, учителя-логопеда під час функціонування психолого-медико-педагогічного консиліуму, організації 
інтегрованого навчання, інклюзії освіти. Це означає, що майбутній логопед повинен бути підготовлений до реалізації своєї поліфункціональності.

Перспективу подальших досліджень вбачаємо в експериментальній перевірці визначених особливостей професійної підготовки майбутніх логопедів у закладах вищої освіти в аспекті професійної діяльності.

\section{ЛІТЕРАТУРА}

Акименко, В. М. (2003). Подготовка студентов-логопедов $к$ коррекции звукопроизношения средствами моделирования (дис.... канд. пед. наук). Ставрополь (Akymenko, V. M. (2003). Preparation of students-speech therapists for correction of sound pronunciation by means of modeling (PhD thesis). Stavropol).

Аслаева Р.Г. (2011). Стратегия социально-профессиональной подготовки дефектологов в педагогическом вузе (дис. .... д-ра пед. Наук). Уфа (Aslaieva, R. H. (2011). Strategy of social and vocational training of defectologists in a pedagogical university (DSc thesis). Ufa).

Бессмертная Н. А. (2003) Организационно-педагогические условия развития профрессиональной компетентности будущих логопедов сельских образовательных учреждений: дис. .... канд. пед. наук. Москва. (Bezsmertnaya N. A. (2003) Organizational and pedagogical conditions for the development of professional competence of future speech therapists of rural educational institutions: dis. ... cand. ped sciences. M oscow).

Болтакова, Н.И. (2013). Формирование коммуникативной компетентности будущих логопедов как необходимое условие подготовки к речевому развитию детей. Проблеми сучасної психології, 20, 60-68 (Boltakova, N.I. (2013). Formation of communicative competence of future speech therapists as a necessary condition for preparation for speech development of children. Problems of modern psychology, 20, 60-68).

Болтакова, Н.И. (2011). Формирование профессиональных компетенций будущего логопеда. Филология и культура, 4, 307-310 (Boltakova, N. I. (2011). Formation of professional competencies of the future speech therapist. Philology and culture, 4 , 307-310).

Борисова, Е. А. (2013). Подготовка будущих учителей-логопедов к самостоятельной профессиональной деятельности. Специальное образование, 4, 80-86 (Borisova, E. A. (2013). Preparation of future speech therapists for independent professional activity. Special education, 4, 80-86).

Жукатинская, Е.Н. (2008). Формирование профрессиональной компетентности будущего учителя-логопеда (дис. ... канд. пед. наук). Липецк (Zhukatinskaia, E. N. (2008). Formation of professional competence of the future speech therapist-teacher (PhD thesis). Lipetsk).

Зодбаева, Б.Д. (2005). Формирование у студентов-дефектологов практической готовности к взаимодействию с дошкольниками с нарушением интеллекта. Школьный логопед, 2, 16-22 (Zodbaieva, B. D. (2005). Formation in studentsdefectologists of practical readiness for interaction with preschoolers with impaired intelligence. School speech therapist, 2, 16-22).

Логопедия (1998). Москва: ВЛАДОС (Speech Therapy (1998). M oscow: VLADOS).

Семаго, Н. Я., Семаго, М.М. (2000). Проблемные дети: основы диагностической и проблемной работы психолога. Москва: АРКТИ (Semago, N. Үа., Semago M.M. 
(2000). Problem children: basics of diagnostic and problem work of a psychologist. Moscow: ARKTY).

Стахова, Л. Л. (2010). Проектирование методической системы развития профессиональной компетентности учителя-логопеда дошкольного образовательного учреждения в условиях профессиональной среды (дис.... канд. пед. наук). Тамбов (Stakhova, L. L. (2010). Designing a methodological system for the development of professional competence of a speech therapist of a preschool education institution in a professional environment (PhD thesis). Tambov).

Султанова, Р. М. (2005). Формирование профессиональной компетентности будущего учителя-логопеда в учебно-педагогической, производственной практике повышенного уровня (дис. ... канд. пед. наук). Ижевск (Sultanova, R. M. (2005). Formation of professional competence of a future teacher-speech therapist in educational and pedagogical, industrial practice of an increased level (PhD thesis). Izhevsk).

Ястребова, Л.А. (2008). Формирование профессионально значимых качеств будущих педагогов-дефектологов (дис.... канд. пед. наук). Армавир Yastrebova, L. A. (2008). Formation of professionally significant qualities of future educatorsdefectologists (PhD thesis). Armavir).

\section{PEЗЮME}

Цимбал-Слатвинская Светлана. Особенности профессиональной подготовки будущих логопедов высших учебных заведениях в аспекте профессиональной деятельности.

В статье раскрыты особенности профессиональной подготовки будущих логопедов в высших учебных заведениях в аспекте профессиональной деятельности. Для их раскрытия определена срера деятельности, функции, требования к подготовке будущих логопедов в высших учебных заведениях. Установлено, что главной обязанностью логопеда является выявление и оказание помощи детям с различными аномалиями в психофизическом развитии. Раскрыта специфика коррекционноразвивающей деятельности будущего логопеда, которая заключается в том, что его речь, сформированная коммуникативная компетентность являются инструментами коррекционного воздействия, от эффрективности применения зависят возможности дальнейшего развития и сочиализации детей и подростков с нарушениями речи, а также успешность профрессионально-педагогического общения с ними, их родителями, коллегами, администрацией.

Ключевые слова: особенности, профессиональная подготовка, будущие логопеды, высшие учебные заведения, профессиональная деятельность.

\section{SUM MARY}

Tsymbal-Slatvinska Svitlana. The features of professional training of future speech therapists in higher education institutions in the aspect of professional activity.

The article describes the features of professional training of future speech therapists in higher education institutions in the aspect of professional activity. In the article we defined the sphere of activity, functions, and requirements for preparation of future speech therapists in higher education institutions. The main responsibility of speech therapists is to identify and assist children with various abnormalities in psychophysical development. We found out that the future speech therapist can carry out his activity in preschool institutions (speech therapists, compensatory and inclusive groups), institutions of general secondary education, special, educational and social rehabilitation centers, speech centers at polyclinics, PM PC (now - IRC). Specific requirements for the speech therapist's personality are 
identified: he performs both psychological and pedagogical correction. The specifics of the corrective-developmental activity of the future speech therapist are revealed. The speech, the formed communicative competence are the tools of corrective influence on them, their parents, colleagues, administration. We indicated the areas of knowledge, and skills in which students should be competent: they perform educational, corrective, compensatory, and rehabilitation work with children with speech disorders; provide conditions for learning disability compensation and corrective programs taking into account disabilities, age and individual peculiarities; promote social rehabilitation, vocational guidance; study and record the dynamics of the child's development; create favorable organizational and pedagogical conditions for children with severe speech disorders (with rhinolalia, stuttering, alalia, aphasia, dysarthria); produce the optimal pedagogical and corrective strategy, etc. Features of professional activity of the future speech therapist are distinguished: polyfunctionality, multidimensionality (internal and semantic integration), diversity (external and institutional integration), versatility (has multiple manifestations in the system) of the speech therapist's functions.

Key words features, professional training, future speech therapists, higher education institutions, professional activity.

УДк 378.018.8:373.5.011.3-051:364-786

\author{
Анна Чередник \\ Уманський державний педагогічний \\ університет імені Павла Тичини \\ ORCID ID 0000-0002-8021-4708
}

DOI 10.24139/2312-5993/2019.07/037-047

\title{
ПІДГОТОВКА МАЙБУТНІХ УЧИТЕЛІВ-РЕАБІЛІТОЛОГІВ ДО РОБОТИ В УМОВАХ ІНКЛЮЗИВНОГО НАВЧАННЯ УЧНІВ: КАТЕГОРІАЛЬНИЙ АПАРАТ
}

У статті здійснено спробу уточнити категоріальний апарат дослідження. На основі аналізу понять «інвалідність», «непрацездатність», «особливі потреби дітей», «порушення розвитку», «дезадаптація», «діти групи ризику», «проблемні діти», «діти з аномальним розвитком», «діти з інвалідністю», «діти з обмеженими можливостями», «особливі діти», «виняткові діти» уточнено терміни «діти 3 особливими освітніми потребами», «інклюзивне навчання». Для розкриття ключового поняття «підготовка майбутніх учителів-реабілітологів до роботи в умовах інклюзивного навчання учнів загальноосвітніх навчальних закладів» розкрито сутність дотичних понять: «корекційно-педагогічна діяльність», «реабілітаційнопедагогічна діяльність».

Ключові слова: дезадаптація, діти групи ризику, діти з інвалідністю, діти з обмеженими можливостями, діти з особливими освітніми потребами, інклюзивне навчання, підготовка майбутніх учителів-реабілітологів.

Постановка проблеми. У будь-якому суспільстві $€$ люди, які мають відхилення у фізичному, психічному або соціальному розвитку. Це означає, що зовнішні обставини, у яких знаходиться людина, або стан ії̈ здоров'я не відповідають певним, прийнятим у даному суспільстві нормам. 